Andrzej Ostrowski

Uniwersytet Marii Curie-Skłodowskiej, Lublin

ORCID: 0000-0001-8374-6884

e-mail: ostrowski.a@poczta.umcs.lublin.pl

\title{
Karsawina i Szestowa krytyka „czystego rozumu”
}

W filozofii rosyjskiej przełomu XIX i XX wieku oraz w okresie nieco późniejszym, uwzględniając przy tym filozofów działających na emigracji po 1922 roku, recepcja szeroko rozumianego racjonalizmu oświeceniowego dotyczyła przede wszystkim filozofii Immanuela Kanta (1724-1804) i była zróżnicowana, dominowały w niej jednak ujęcia mniej lub bardziej krytyczne. Przykładem tych ostatnich są między innymi poglądy Lwa Karsawina (1882-1952) i Lwa Szestowa (1866-1938). Z jednej strony byli oni przedstawicielami filozofii religijnej, z drugiej zaś wypracowali skrajnie odmienne stanowiska: Karsawin - filozofię idealistyczną (filozofię wszechjedności), Szestow - filozofię egzystencjalną. Celem artykułu jest wykazanie, że pomimo odmienności ich stanowisk krytyka "czystego rozumu" wychodziła od bardzo podobnych przesłanek i miała przynajmniej jedno wspólne źródło inspiracji - filozofię Kanta.

\section{Typowy Rosjanin i jego radykalna postawa}

Lew Karsawin w rozprawie zatytułowanej Wschód, Zachód i idea rosyjska (Восток, Запад и русская идея, 1922), charakteryzując Rosjanina, stwierdził między innymi:

Rosjanin nie może istnieć bez absolutnego ideału, chociaż często ze wzruszającą naiwnością za taki przyjmuje coś całkowicie niewłaściwego. Jeżeli jest człowiekiem religijnym, to dochodzi do skrajnego ascetyzmu, pra- 
wowiary lub herezji. Jeżeli zamieni absolutny ideał na system Kanta, to gotów wyskoczyć przez okno z piątego piętra w celu udowodnienia fenomenalizmu świata zewnętrznego ${ }^{1}$.

$Z$ racji tego, że Karsawin w cytowanej wypowiedzi milcząco przyjął kwantyfikator ogólny - „każdy Rosjanin”, to w celu uniknięcia błędu generalizacji należy założyć, że pisząc o Rosjaninie, miał na myśli tylko typowego Rosjanina. Zawężenie pod względem typologicznym potencjalnego grona osób, do których odnosi się przedstawiona charakterystyka, nie ułatwia jednak zadania polegającego na podaniu przykładów, szczególnie w odniesieniu do tych, którzy byliby zainteresowani opisanym sposobem weryfikacji fenomenalizmu świata zewnętrznego, a w rezultacie systemu Kanta. Pomimo sformułowanych wątpliwości można przynajmniej hipotetycznie przyjąć, że dobrym przykładem typowego Rosjanina, który spełnia postawione przez Karsawina kryteria, byłby Lew Szestow, między innymi ze względu na bezkompromisową postawę w kwestiach wiary, radykalizm głoszonych poglądów oraz bezpardonową krytykę filozofii Kanta, ale również ze względu na „wzruszającą naiwność", z jaką za absolutny ideał przyjął zasadę wszechmocy Boga, dla którego wszystko jest możliwe; na przykład aby byłe uczynić niebyłym, a niebyłe byłym ${ }^{2}$. „Wzruszająca naiwność" jest w tym przypadku sądem wartościującym sformułowanym w ramach „właściwego" stanowiska filozoficznego (tu: idealizm Karsawina). Sąd ten może być również sformułowany przynajmniej z punktu widzenia zdrowego rozsądku, dzięki któremu nie wszyscy typowi Rosjanie przyjmują za absolutny ideał coś całkowicie niewłaściwego.

Drugim przykładem typowego Rosjanina, jednak ze zgoła odmiennych powodów, byłby sam Karsawin. Zasadniczą przesłanką postawionej tezy jest przyjęcie za absolutny ideał „właściwie” pojętej idei rosyjskiej. Należy ją rozumieć zarazem jako to, co przez naród rosyjski jest już zaktualizowane, jak i to, co w danym momencie jest aktualizowane we wszystkich aspektach szeroko pojętego życia. Karsawin zwrócił uwagę na to, że jego sposób rozumienia idei rosyjskiej, w przeciwieństwie do wielu innych autorów zajmujących się tym zagadnieniem, nie czyni z niej idei przyszłości (czyli czegoś, co w dopiero przyszłości będzie zrealizowane), lecz ideę, która przyszłość aktualnie wyznacza ${ }^{3}$.

$\mathrm{W}$ ujęciu formalnym ideę rosyjską należy natomiast rozumieć jako element istotnościowy, czyli warunkujący miejsce i cel Rosji w świecie,

1 Лев Платонович Карсавин, „Восток, Запад и русская идея”, w: Лев Платонович Карсавин, Сочинения (Москва: РАРИТЕТ, 1993), 214.

2 Por. Пев Шестов, Киргегард и экзистенчизильная философия. Глас вопиющего в пустыне (Москва: Прогресс - Гнозис, 1992), 229.

3 Por. Карсавин, „Восток, Запад и русская идея”, 164-165. 
ale także warunkujący bycie Rosjaninem. W sposób rozumienia idei rosyjskiej jako elementu istotnościowego wpisane jest założenie zależności zwrotnej; idea rosyjska warunkuje bycie Rosjaninem (między innymi: uświadomienie sobie idei rosyjskiej i jej zaakceptowanie), natomiast bycie Rosjaninem zobowiązuje do urzeczywistnienia w pełni idei rosyjskiej (realizacji celu Rosji).

Wskazanie na Karsawina jako przykład typowego Rosjanina jest oparte zarówno na tym, że sam zaproponował sposób rozumienia idei rosyjskiej, jak i na wzmiankowanej zależności zwrotnej. Dodatkową przesłanką jest to, że ze względu na świadomość możliwości przyjęcia za absolutny ideał czegoś całkowicie niewłaściwego Karsawin - w przeciwieństwie do Szestowa - nie popełnił błędu, o którym mowa w cytowanym fragmencie jego wypowiedzi na temat typowego Rosjanina.

Ideę rosyjską Karsawin analizował w ramach filozofii historii, jednak ważnym - również dla prowadzonych rozważań na temat krytyki „czystego rozumu" - bezpośrednim kontekstem tych analiz była krytykowana przez niego szeroko rozumiana kultura Wschodu i Zachodu, co znajduje swoje odzwierciedlenie w tytule rozprawy, z której pochodzi cytowany fragment. Do kontekstu kulturowego nawiążę $w$ dalszej części rozważań, natomiast teraz zwrócę uwagę na to, że w odniesieniu do analizowanego przez Karsawina zagadnienia absolutnego ideału interesowało go jedno - częste przyjmowanie przez typowych Rosjan za absolutny ideał czegoś całkowicie niewłaściwego wraz z wynikającymi $\mathrm{z}$ tego niedorzecznymi konsekwencjami bez względu na to, czy przykładowo rzecz dotyczy wiary, czy też systemu Kanta. W odniesieniu do tego drugiego zakładam, że w mniemaniu Karsawina piąte piętro to wystarczająca wysokość, aby wyskakując przez okno, nawet przy ewentualnym wystąpieniu wszelkich okoliczności sprzyjających zachowaniu życia, tego życia się pozbawić. Deklarowana gotowość do skoku z pewnością podnosi wiarygodność egzemplifikacji jednej z fundamentalnych - przynajmniej w oparciu o podane przez Karsawina przykłady przyjęcia za absolutny ideał czegoś całkowicie niewłaściwego - cech typowego Rosjanina, którą nazwę radykalizmem, w sensie bezkompromisowości działania w myśl zasady „wszystko albo nic”. Radykalizm nie wyczerpuje charakterystyki typowego Rosjanina, a podane przykłady umożliwiają zniuansowanie zagadnienia, chociażby o istotową (tu: wynikającą z faktu bycia Rosjaninem) potrzebę posiadania absolutnego ideału. W rozważaniach skupię uwagę jednak na radykalizmie, ponieważ moim zdaniem jest to najważniejsza cecha, której zaakceptowanie stanowi jedną z przesłanek wyjaśnienia roli podanych przez Karsawina przykładów przyjęcia za absolutny ideał czegoś całkowicie niewłaściwego.

Z pewnością istnieje jakaś grupa osób, nie tylko Rosjan, które straciły życie, wyskakując przez okno z piątego piętra. Zakładam jednak, że trudno znaleźć przypadek pozbawienia się w ten sposób życia z powodu 
systemu Kanta. Ani Karsawin, ani Szestow jako typowi Rosjanie, którzy spełniali wypracowane przez Karsawina kryteria, również nie próbowali tego sposobu. W oparciu o tę przesłankę przewrotnie i nieco ironicznie stawiam pytanie, które może pełnić rolę podtytułu dookreślającego kierunek rozważań na temat Karsawina i Szestowa krytyki „czystego rozumu”. Pytanie brzmi: „Dlaczego Lwy nie wyskoczyłyby przez okno z piątego piętra?".

Udzielając wstępnej odpowiedzi na postawione pytanie, można powiedzieć, że Karsawin nie był gotów do podjęcia takiej próby z tego powodu, że - jak już zostało stwierdzone - nie popełnił błędu polegającego na niewłaściwym przyjęciu czegoś za absolutny ideał. Szestow natomiast, jak wynika z jego biografii oraz treści i sposobu głoszonych poglądów, co najwyżej mógł być tylko gotowy do oddania skoku. Tezę tę traktuję jako zdroworozsądkowe założenie, uznając, że zdrowy rozsądek w większości przypadków chroni przed tragicznymi w skutkach decyzjami, nie tylko z powodu filozoficznych teorii. W związku z tym warto zastanowić się nad "gotowością wyskakiwania przez okno z piątego piętra $\mathrm{z}$ powodu systemu Kanta w celu udowodnienia fenomenalizmu świata zewnętrznego" i spróbować odpowiedzieć na pytanie, dlaczego Karsawin przytoczył tak niedorzeczny przykład. Możliwe są przynajmniej trzy odpowiedzi.

\section{Radykalizm jako wada typowego Rosjanina}

Odpowiedź pierwsza zakłada, że Karsawin wyśmiewał postawę typowego Rosjanina, a dokładnie rzecz ujmując - jedną z jego podstawowych cech i wad, jaką jest bezkrytyczny radykalizm, bez względu na to, w czym ten radykalizm się ujawnia i co jest przedmiotem radykalnego działania. Można przyjąć, że Karsawin posłużył się następującą zasadą: im bardziej niedorzeczny przykład, tym bardziej przemawia do wyobraźni i skuteczniej zwraca uwagę na dany problem. W podanych przez niego przykładach implicite zawarte jest założenie, że typowy Rosjanin, wychodząc od danych przesłanek, zgodnie ze swoją naturalną cechą (tu: bezkrytyczny radykalizm) działa nie tylko radykalnie, ale również konsekwentnie (systemowo) oraz... - dalej należy wskazać na dwie możliwości interpretacyjne - a) racjonalnie, b) nieracjonalnie. Racjonalnie, czyli zgodnie z tym, co dyktuje mu rozum, dochodzi do skrajności, często ujawniających się niedorzecznością (na przykład: herezja, gotowość do wyskoczenia przez okno). Nieracjonalnie, czyli nie bacząc na to, co dyktuje rozum, ze względu na aktualnie wyznawany absolutny ideał również dochodzi do tych samych negatywnych skrajności. Ten sam efekt można zatem osiągnąć w odmienny sposób, ale w obu wyróżnionych przypadkach potrzebny jest poprzedzający je radykalizm 
i konsekwentne (systemowe) działanie. W przypadku działania nieracjonalnego przyjąłem założenie, że może ono być zarazem konsekwentne (systemowe), co oznacza, że nie jest sprzeczne $z$ radykalizmem i tym samym nie znosi go.

W kontekście zaproponowanej interpretacji należałoby postawić pytanie o przyczynę racjonalnego lub nieracjonalnego działania. Ze względu na ograniczenia wynikające $\mathrm{z}$ formy wypowiedzi, jaką jest artykuł, $\mathrm{z}$ konieczności tylko odnotowuję ten problem.

Zastanawia również to, że w przypadku kwestii religijnej Karsawin napisał, że Rosjanin "dochodzi do" na przykład herezji. Natomiast w przypadku systemu Kanta stwierdził, że Rosjanin jest „gotów wyskoczyć przez okno". O ile w pierwszym przypadku sprawa jest przesądzona, ponieważ typowy Rosjanin, postępując radykalnie i konsekwentnie oraz a) racjonalnie lub b) nieracjonalnie, dojdzie prędzej lub później do skrajności $\mathrm{w}$ postaci herezji, o tyle $\mathrm{w}$ drugim przypadku sprawa przesądzona nie jest, w tym sensie, że mowa tylko o gotowości do skoku. Biorąc pod uwagę ten rodzaj różnicy, należy stwierdzić, że ujawniające się niedorzecznością skrajności, o których pisał Karsawin, nie są ze sobą porównywalne. Niemniej jednak w myśl przyjętych założeń interpretacyjnych gotowość do skoku jest nieuchronna, ponadto Karsawin założył możliwość zamiany danego absolutnego ideału na inny. $Z$ tego powodu można stwierdzić, że gotowość do skoku jest porównywalna z przykładową herezja, natomiast z punktu widzenia zdrowego rozsądku pierwsze i drugie może być uznane za rodzaj szaleństwa.

\section{Wiara bez rozumu, rozum bez wiary}

Zgodnie z drugą odpowiedzią Karsawin dopuścił się zasadnego przejaskrawienia cech typowego Rosjanina. Dodatkowo zakładam, że dobór przykładów ilustrujących radykalizm typowego Rosjanina nie jest przypadkowy, co oznacza, że Karsawin, w przeciwieństwie do pierwszej propozycji odpowiedzi uwzględniającej tylko działanie racjonalne i nieracjonalne, zwrócił również uwagę na zagadnienie wiary i rozumu. Na tej podstawie można postawić tezę, że Karsawin celowo przejaskrawił radykalną postawę Rosjanina po to, aby wyśmiać zarówno zdanie się tylko na "czystą wiarę" (czyli taka, która programowo abstrahuje od rozumu jako źródła wiedzy), jak i zdanie się tylko na "czysty rozum” (czyli taki, który programowo abstrahuje od wiary jako źródła wiedzy) ${ }^{4}$. Przywołany system Kanta ze względu na wynikające konsekwencje, które Karsawin sprowadził do fenomenalizmu, jest nie tylko przedmio-

${ }^{4}$ W rozważaniach pomijam inne ewentualne pozarozumowe źródła wiedzy, na przykład przeżycie (doświadczenie) estetyczne. 
tem krytyki, ale również przykładem niedorzeczności, jakie wynikają z odwołania się do "czystego rozumu”.

Przy tym sposobie interpretacji radykalizm jako jedna $\mathrm{z}$ podstawowych cech typowego Rosjanina nie jest wada, lecz zaleta, ponieważ ujawnia niedorzeczne konsekwencje zarówno przy zdaniu się tylko na „czystą wiarę", jak i przy zdaniu się tylko na „czysty rozum”. Natomiast w dalszym ciągu aktualne jest implicite przyjęte przez Karsawina założenie, że typowy Rosjanin, wychodząc od danych przesłanek, działa radykalnie i konsekwentnie (systemowo) oraz ... - dalej należy wskazać tym razem już na trzy możliwości:

a) zgodnie z "czystym rozumem" (sola ratio), czyli zgodnie z tym, co dyktuje mu tylko rozum, dochodzi do skrajności, często ujawniających się niedorzecznością (na przykład: herezja, gotowość do wyskoczenia przez okno);

b) zgodnie z „czystą wiarą" (sola fide), czyli w oparciu o prawdy wiary, nie bacząc przy tym na to, co dyktuje „czysty rozum”, dochodzi do tych samych skrajności.

O ile „czysty rozum” ze względu na ściśle wytyczony zakres przedmiotowy, stosowanie praw logiki oraz warunek intersubiektywności jest określony w tym sensie, że nie może być rozumiany w sposób dowolny, o tyle "czysta wiara" nie jest określona, zatem jej zakres przedmiotowy, dogmaty oraz forma mogą być dowolne. Tezę, że „czysta wiara” nie jest określona, można postawić tylko ze względu na ujęcie formalne, natomiast w filozofii Karsawina "czysta wiara” odpowiada wierze chrześcijańskiej, której przeciwstawił on „właściwie” rozumianą wiarę chrześcijańską - czyli taka, jak według niego powinna być ona pojmowana. W filozofii Karsawina terminem oddającym „właściwe” pojmowanie wiary chrześcijańskiej jest „panenteizm" ${ }^{\prime 5}$;

c) zgodnie z tym, co wynika z połączenia "czystej wiary” i „czystego rozumu” (fides et ratio), czyli zgodnie z tym, co dyktują mu zarówno wiara, jak i rozum, również dochodzi do tych samych skrajności, które często ujawniają się niedorzecznością.

Karsawin nie zaakceptowałby jednak wyodrębnionego ze względów formalnych stwierdzenia zawartego w punkcie c), w którym jest mowa o dochodzeniu na podstawie połączenia "czystego rozumu" i „czystej wiary” (fides et ratio) do skrajności, często ujawniających się niedorzecznością. Podanie przez Karsawina dwóch przykładów (bycie człowiekiem religijnym, weryfikacja systemu Kanta) w związku z zagadnieniem przyjęcia za absolutny ideał czegoś całkowicie niewłaściwego można bowiem odczytać jako wskazanie na dwa zasadnicze problemy: wiary bez rozumu oraz rozumu bez wiary. $W$ propozycji Karsawina rozwiązanie tych problemów polega na ujęciu całościowym,

\footnotetext{
5 Por. Карсавин, „Восток, Запад и русская идея”, 169.
} 
czyli na uwzględnieniu zarówno wiary, jak i rozumu (fides et ratio), co z kolei przy dodatkowym przyjęciu za absolutny ideał tego, co właściwe (tu: idea rosyjska), chroni przed wskazanymi skrajnościami, często ujawniającymi się niedorzecznością.

\section{Ironiq̨ w system Kanta}

Odpowiedź trzecia uwzględnia hipotezę, że cytowany fragment wypowiedzi Karsawina jest opartą na ironii krytyką filozofii Kanta, której nie warto poświęcać szczegółowej analizy. Wystarczyło zatem ukazać ją wybiórczo, w sposób prześmiewczy, poprzez zwrócenie uwagi na jej niedorzeczne konsekwencje, ale za to $\mathrm{z}$ całkowita, godną ironii $\mathrm{w}$ stopniu najwyższym, powagą. Nie bez znaczenia jest również to, że przyjęty sposób krytyki ma znacznie szerszą skalę oddziaływania niż wywód filozoficzny, w którym dowodzi się, że dane stanowisko jest błędne.

Karsawin celowo przejaskrawił więc postawę typowego Rosjanina, żeby dokonać efektownej krytyki systemu Kanta. W komentarzu do podjętej krytyki zwrócę uwagę na trzy kwestie. Po pierwsze, na podstawie cytowanej wypowiedzi można sądzić, że Karsawin, skoro nie przeprowadził żadnych analiz, skierował swoją wypowiedź tylko do czytelnika, który przynajmniej w ogólnym zarysie zna system Kanta. Wystarczy hasło „system Kanta” oraz „fenomenalizm świata zewnętrznego" i taki czytelnik już wie, o co chodzi, a rola Karsawina sprowadziła się tylko do podsunięcia podpowiedzi, jak udowodnić fenomenalizm świata zewnętrznego.

Podpowiedź jest niestety tendencyjna, ponieważ to, że świat zewnętrzny, czyli tak zwany "świat fizyczny", jest tylko fenomenem warunkowanym między innymi subiektywną aprioryczną formą czasu i subiektywną aprioryczną formą przestrzeni - o czym Karsawin $\mathrm{w}$ analizowanym tekście w ogóle nie wspomina - nie przesądza o tym, że w przeciwieństwie do ujęcia zdroworozsądkowego skakanie przez okno z piątego piętra skończy się tragedią. Ponadto nawet gdyby skakanie przez okno każdorazowo kończyło się tragedia, to takie wydarzenie niczego nie udowadnia (niczego nie zmienia), a jego wyjaśnienie, podobnie jak wyjaśnienie innych obserwowalnych wydarzeń, możliwe jest w ramach systemu Kanta. Podpowiedź jest tendencyjna, a jako argument jest nie do obronienia, ale - jak sądzę - jest zarazem na tyle sugestywna, że w większości przypadków (zakładam, że nie dotyczy to na przykład zwolenników systemu Kanta) zwalnia czytelnika z myślenia o sensowności takiego sposobu weryfikacji fenomenalizmu świata zewnętrznego. Obliczona jest natomiast na to, że zaproponowany sposób weryfikacji zostanie przez czytelnika skonfrontowany ze zdrowym rozsądkiem, co w efekcie doprowadzi przynajmniej do refleksji, że w ramach „czystego 
rozumu" można było stworzyć aż tak dziwaczny system, skoro udowodnienie jego zasadności wymaga wyskakiwania przez okno z piątego piętra. Zdrowy rozsądek podpowiada, że dla systemu filozoficznego, jaki by nie był, nie warto tego robić i dlatego w dalszej konsekwencji, oprócz lekceważącego uśmiechu czytelnika, system Kanta bez rzetelnego zaznajomienia się z nim powinien zostać odstawiony do lamusa.

Po drugie, rozprawa na temat Wschodu, Zachodu i idei rosyjskiej była skierowana nie tylko do filozofów, ale przede wszystkim do szerokiego kręgu odbiorców, którzy interesowali się kulturowymi, w tym religijnymi, różnicami między Wschodem i Zachodem oraz „absolutnym ideałem", jakim jest idea rosyjska - dyżurny temat filozofii rosyjskiej w wieku XIX i XX'. Zwracam na to uwagę, ponieważ można przypuszczać, że po takiej „reklamie” systemu Kanta mało kto byłby skłonny zainteresować się nim, skoro potraktowany na serio mógł doprowadzić do niedorzeczności i tragedii.

Po trzecie, mając na względzie to, że Karsawin celowo zestawił zagadnienie bycia człowiekiem religijnym $\mathrm{z}$ zagadnieniem weryfikacji systemu Kanta (oba przykłady, biorąc pod uwagę skrajnie negatywne konsekwencje, ilustrują niewłaściwe przyjęcie czegoś za absolutny ideał) oraz dopuszczał zamianę pierwszego przykładu na drugi, można przyjąć, że nie wprost zarzucał Kantowi nieuwzględnienie w racjonalistycznym systemie wiary i Boga jako elementów niezbędnych do wyjaśnienia szeroko pojętej rzeczywistości.

Reasumując odpowiedź na pytanie o cel przytoczenia przez Karsawina tak niedorzecznego przykładu sposobu weryfikacji fenomenalizmu Kanta, można stwierdzić, że - po pierwsze - Karsawina najwyraźniej nie przekonało to, co Kant miał do powiedzenia między innymi na temat roli zmysłów w procesie poznawczym oraz rozumu praktycznego. Do skrytykowania systemu Kanta najprawdopodobniej wystarczyła Karsawinowi przeprowadzona przez samego Kanta krytyka metafizyki ( $w$ analizowanym tekście również nie ma odniesienia do krytyki metafizyki) i niestety łatwa do obalenia, zatem bardzo słaba argumentacja dotycząca sposobu weryfikacji fenomenalizmu świata zewnętrznego, o czym była już wzmianka.

Po drugie, krytyka systemu Kanta w wydaniu Karsawina to krytyka racjonalizmu, czyli "czystego rozumu” jako władzy poznawczej, która z założenia daje wiedzę pewną tym bardziej że abstrahuje od

${ }^{6}$ Karsawin, podejmując się rozważań, których przedmiotem jest idea rosyjska, włączył się tym samym w prowadzoną na szeroką skalę narodową dyskusję na ten temat; por. Карсавин, „Восток, Запад и русская идея”, 157-158. 
wszystkiego, co nie jest rozumem lub od tego rozumu nie pochodzi. System Kanta był zatem dla Karsawina tylko typowym przykładem tak pojętego racjonalizmu.

Po trzecie, ze względu na przesłankę, że w cytowanej wypowiedzi Karsawina chodzi o krytykę „,czystego rozumu” przeprowadzoną na reprezentatywnym przykładzie systemu Kanta, zaproponowaną interpretację można poszerzyć o krytykę racjonalizmu oświeceniowego, zakładając, że Kant był jego typowym przedstawicielem, lub wręcz poszerzyć o racjonalizm w ogóle. Teza, że system Kanta posłużył Karsawinowi tylko za przykład, może z kolei stanowić przesłankę do wyjaśnienia, dlaczego nie podjął się on rzetelnej analizy tego systemu, która powinna poprzedzić rzetelną krytykę.

\section{Pomiędzy Wschodem i Zachodem a Atenami i Jerozolima}

Podanie przez Karsawina dwóch przykładów (bycie człowiekiem religijnym, weryfikacja systemu Kanta) w związku z zagadnieniem przyjęcia za absolutny ideał czegoś całkowicie niewłaściwego oraz wskazana przez niego możliwość zastąpienia pierwszego przykładu drugim nie sa, jak zostało to już stwierdzone, przypadkowe, co oznacza, że chodziło o osiągnięcie określonego celu. Wspominam o tym ponownie, ponieważ postawioną tezę można wzmocnić poprzez uwzględnienie wzmiankowanego już kontekstu rozważań Karsawina. Dodatkowo kontekst ten, ze względu na zachodzące analogie, warto porównać z podobnym kontekstem rozważań Szestowa.

Kontekstem dla cytowanej wypowiedzi Karsawina są rozważania o Wschodzie i Zachodzie; szczególnie dotyczy to porównywania szeroko pojętej kultury, filozofii i religii tych „,światów”, które pomimo ewidentnych różnic są w systemie filozoficznym Karsawina aspektowym przejawem Absolutu. Omawiane przez Karsawina Wschód i Zachód należy zatem odczytywać jako symboliczne, chociaż nie w pełni wyczerpujące wieloaspektowe ujęcie przejawu Absolutu. Pełnię wyrazu tego przejawu Karsawin odnajdywał w idei rosyjskiej, wpisując się tym samym w nurt dyskusji o światowej roli i celu, jaki stoi przed Rosjanami i Rosją.

Chociaż zasadniczy zamysł Szestowa był zupełnie inny, to w jednym ze swoich późnych dzieł, w którym znalazły się liczne powtórzenia wcześniej wyartykułowanych już myśli, zwrócił uwagę na kontekst kulturowy Zachodu i Wschodu. Szestow, inspirując się poglądami Tertuliana, kontekst ten wyraził w tytule dzieła Ateny $i$ Jerozolima ${ }^{7}$, co

7 Por. Лев Шестов, „Афины и Иерусалим”, w: Лев Шестов, Сочинения в 2-х mомах (Москва: НАУКА, 1993, Том 1. 
$\mathrm{w}$ najprostszym ujęciu interpretacyjnym trzeba rozumieć jako symboliczny wyraz rozumu i wiary. Kolejność nie jest przypadkowa. Szestow, w przeciwieństwie do Karsawina, nie był ani historykiem, ani filozofem historii, nie był też teoretykiem kultury, ale jako myśliciel krytykujący dotychczasową filozofię, przede wszystkim utożsamioną przez niego z szeroko pojętym racjonalizmem, w pierwszej kolejności zwrócił uwagę na rozum - Ateny, żeby następnie na różne sposoby przeciwstawić mu wiarę - Jerozolimę.

Pomimo wspólnego odniesienia do szerokiego kontekstu rozważań odwrócony porządek, czyli Wschód i Zachód u Karsawina oraz Ateny i Jerozolima u Szestowa, świadczy o zasadniczej różnicy w poglądach obu filozofów. Karsawin, zaczynając rozważania od Wschodu - religii, poprzez Zachód - rozum, skończył na idei rosyjskiej, czyli na syntetyzującym (w przeciwieństwie do aspektowego) ujęciu Absolutu - filozofii wszechjedności. Natomiast Szestow, podkreślając dramaturgię losu człowieka (resp. ludzkości) i wspierając się przy tym na filozofii Edmunda Husserla i Sørena Kierkegaarda, stanął przed "gigantycznym problemem: Entweder-Oder" (Albo-albo) - filozofią egzystencjalną. Był to ten sam problem, przed którym także - jego zdaniem - stanęli zarówno Husserl, jak i Kierkegaard ${ }^{8}$.

Zdaniem Szestowa gigantyczny problem, z którym musiał zmierzyć się Husserl, wyraża się $\mathrm{w}$ tym, że ze względu na ujawnioną w czasach współczesnych możliwość zrelatywizowania wszelkich prawd, dotychczas uznawanych za wieczne i niezachwiane, „albo my wszyscy jesteśmy wariatami, albo prawda »Sokrates został otruty « jest wieczną prawdą obowiązującą wszystkie bez wyjątku świadome istoty" .

W przypadku Kierkegaarda gigantyczny problem wyraża się natomiast w tym, że "albo wieczne prawdy, które rozum odkrywa w bezpośrednich danych świadomości, są prawdami przemijającymi, i potworności, które stały się udziałem Hioba [...], wszystkie te okropności, zgodnie z wolą tego, kto stworzył i wszechświat, i ludzi zaludniających wszechświat, zamieniają się w nicość potworności sennego koszmaru, niepodzielnie panujące nad świadomością śpiącego człowieka, albo żyjemy w szalonym świecie"10.

W przypadku Szestowa, który nawiązywał do filozofii Husserla i Kierkegaarda jako późnych źródeł inspiracji, gigantyczny problem

8 Por. Lew Szestow, „Pamięci wielkiego filozofa (Edmund Husserl)”, w: tenże, Spekulacja $i$ objawienie, przeł. Jacek Chmielewski (Kęty: Wydawnictwo Marek Derewiecki, 2007), 264. W tekście, do którego odwołuje się Szestow, zapożyczając od Kierkegaarda zwrot „albo-albo", nie używał oryginalnego duńskiego zwrotu Enten-Eller, tylko zgodnie z niemieckim przekładem Entweder-Oder.

9 Tamże, 264.

10 Tamże. 
manifestuje się podobnie: albo Bóg może byłe uczynić niebyłym, a niebyłe byłym, co w „normalnym świecie” jest ideą szaloną albo „normalny świat" jest nienormalny.

Karsawin syntetyzował i uogólniał, a w efekcie stworzył idealistyczny system (filozofię wszechjedności), który uwzględnia każde indywiduum jako dokonujący się na którymś z poziomów kolejny z rzędu przejaw (moment) Absolutu ${ }^{11}$. Innymi słowy, Absolut przejawiający się na danym poziomie tego przejawu jest obserwowalną dla pewnego rzędu swoich przejawów (momentów) rzeczywistością we wszystkich aktualnych oraz potencjalnych (przyszłych) aspektach swojego przejawu. Tak rozumiany Absolut wyrażony w idei rosyjskiej to absolutny ideał, bez którego Karsawin jako typowy Rosjanin nie mógł żyć. Natomiast absolutny ideał Szestowa, bez którego jako typowy Rosjanin nie mógł żyć, to Bóg, który byłe może uczynić niebyłym, a niebyłe byłym. Przyjęcie tej zasady skutkuje permanentnym (nie jest to zatem jednorazowy akt) odrzucaniem konieczności (anankē) na rzecz stwarzania możliwości dla nieograniczonych możliwości - możliwość możliwości. Pomimo tej ewidentnej różnicy obaj filozofowie w podobny sposób krytykowali „czysty rozum". Obaj robili to negatywnie, odnosząc się do systemu Kanta jako przykładu nie tylko racjonalizmu oświeceniowego, ale również racjonalizmu w ogóle. Obaj, chociaż zwracając uwagę na inne przesłanki, robili to w lakoniczny sposób.

\section{Deus ex machina}

W nawiązaniu do omówionego kontekstu rozważań, który w filozofii Karsawina jest wyrażony zwrotem „Wschód i Zachód”, w filozofii Szestowa zwrotem "Ateny i Jerozolima”, natomiast w odniesieniu do obu filozofii zwrotem "rozum i wiara”, jeszcze raz uwagę skupię na dokonanym przez Karsawina doborze przykładów (bycie człowiekiem religijnym, weryfikacja systemu Kanta) w związku z zagadnieniem przyjęcia za absolutny ideał czegoś całkowicie niewłaściwego. Tym razem, wykorzystując dotychczas omówione modelowe ujęcia radykalnej postawy, skupię uwagę na zasygnalizowanej już możliwości uznania Szestowa za typowego Rosjanina.

Przytaczane przez Karsawina przykłady, przy jednoczesnym zaakceptowaniu zaproponowanych założeń interpretacyjnych w odniesieniu do typowego Rosjanina, zatem radykalnego oraz posługującego się "czystym rozumem", dają podstawę do stwierdzenia, że pomimo

${ }^{11}$ Dokładniej rzecz ujmując, indywiduum, czyli przejaw (moment) Absolutu, jest możliwy do rozpatrzenia jako szereg swoich przejawów (momentów - moment to indywidualizacja podmiotu). Por. Карсавин, „Восток, Запад и русская идея”, 160. 
odmienności tego, co wyraża Wschód i Zachód (odpowiednio: religia i system Kanta jako przykład racjonalizmu w ogóle), uznanie ich za absolutny ideał i tym samym ich urzeczywistnianie (w sensie życia zgodnego z właściwymi dla nich regułami) doprowadzi do podobnych, a w skrajnych przypadkach do tych samych konsekwencji - szaleństwa.

Przeciwstawienie „,czystemu rozumowi” ,czystej wiary” nie wynika tylko z możliwości, jakie daje formalne ujęcie przytaczanych przez Karsawina przykładów przyjmowania przez typowego, zatem radykalnego, Rosjanina za absolutny ideał czegoś całkowicie niewłaściwego, lecz ma również swoje przesłanki praktyczne. W Rosji, szczególnie w ostatnich dekadach XIX i pierwszych XX wieku, pojawiało się bowiem wiele religijnych sekt, które można uznać za przykład radykalizmu występującego w parze z "czystą wiarą", doprowadzającego do skrajnego ascetyzmu i jakiejś formy herezji. Symbolicznym reprezentantem takiej postawy i sposobu życia, docenionych również w filozoficznej literaturze przedmiotu, był jurodiwy - święty idiota, jak określił tę postać Cezary Wodziński ${ }^{12}$. Jurodiwy nie dba o sprawy przyziemne, neguje ujęcie rozumowe, zdrowy rozsądek, konwenanse, obyczaje, ład społeczny, prawo, innymi słowy - wszystko to, co jest dziełem człowieka, a przeczy prawdzie Bożej. „Mądrość” jurodiwego nie jest bowiem mądrością tego świata.

Na wstępie rozważań założyłem, że typowym Rosjaninem spełniającym wyznaczone przez Karsawina kryteria, oprócz niego samego, byłby również Lew Szestow, z tą różnica, że ten drugi - rozpatrując rzecz z perspektywy filozofii Karsawina - przyjął za absolutny ideał coś całkowicie niewłaściwego. Ponadto oba wymienione przez Karsawina przykłady (bycie człowiekiem religijnym, weryfikacja systemu Kanta) w związku z zagadnieniem przyjęcia za absolutny ideał czegoś całkowicie niewłaściwego bardzo dobrze oddają filozoficzne stanowisko Szestowa. Przypomnę, że podstawowe przesłanki, które przemawiają za wytypowaniem Szestowa, to: bezkompromisowa postawa w kwestiach wiary, radykalizm głoszonych poglądów, bezpardonowa krytyka racjonalizmu, w tym w sposób szczególny filozofii Kanta, przyjęcie za absolutny ideał zasady wszechmocy Boga, dla którego wszystko, w pełnym tego słowa znaczeniu, jest możliwe. Szestow podważał również postawę zdroworozsądkowa, nie przywiązywał wagi do obowiązujących norm społecznych i obyczajowych, w zależności od potrzeb postulował nawet odstępstwo od nich.

12 Por. Cezary Wodziński, Św. Idiota. Projekt antropologii apofatycznej (Gdańsk: słowo/obraz terytoria, 2009). 
Pomimo tego, że pod wieloma względami, które dadzą się sprowadzić do głoszonej przez Szestowa zasady sola fide ${ }^{13}$, można go zaliczyć do grona jurodiwych, to nie był on jednak jego przedstawicielem $z$ jednego zasadniczego powodu. Przyjmując radykalną postawę, zgodnie z tym, co dyktuje wiara i rozum (zatem także przy wykorzystaniu zasad logiki), podważał rozum i rozumienie ${ }^{14}$. Innymi słowy, wiarą i rozumem (fides et ratio) zwalczał "czysty rozum”, natomiast z powodu przyjęcia takiego sposobu walki ${ }^{15}$ należy stwierdzić, że również nie opowiadał się wyłącznie za "czystą wiarą". Pod tym względem, pomimo odmiennych stanowisk filozoficznych, poglądy Szestowa w ujęciu teoretycznym (w odróżnieniu od praktycznego ich wdrażania, co w przypadku egzystencjalizmu Szestowa wyraża się w twierdzeniu, że jego sposób życia odzwierciedlał głoszone poglądy) są zbieżne z poglądami Karsawina.

W przypadku filozofii Szestowa podanie przykładów krytyki racjonalizmu, nie wyłączając przy tym systemu Kanta, jest trudne w tym sensie, że jest ich bardzo dużo. Praktycznie w każdej napisanej przez niego rozprawie czytelnik ma do czynienia z mniej lub bardziej wyszukaną formą krytyki racjonalizmu. $Z$ tego powodu zwrócę uwagę tylko na jeden, ale za to - moim zdaniem - reprezentatywny przykład, który w zasadny sposób można odnieść do analizowanego fragmentu wypowiedzi Karsawina. Ponadto przykład ten jest - jak sądzę - wystarczający, aby udzielić odpowiedzi na pytanie, dlaczego Lew Szestow, pomimo tego, że był - jak wskazują na to liczne przesłanki - typowym, zatem radykalnym, Rosjaninem, pomimo tego, że zgodnie z wytycznymi wiary i rozumu wyrażał gotowość do udowodnienia fenomenalizmu świata zewnętrznego w sposób zaproponowany przez Karsawina, nie wyskoczyłby przez okno z piątego piętra.

We wspomnianym już dziele Ateny i Jerozolima Szestow napisał:

Przed Kantem stało pytanie, czy możliwa jest metafizyka, gdzie znajduje się to źródło, z którego cierpiąca ludzkość mogłaby zaczerpnąć wody życia (nie trzeba zapominać, że według Kanta metafizyka traktuje o Bogu, nieśmiertelności duszy i wolnej woli), a on troszczył się wyłącznie o to, by dogodzić rozumowi, który ani z Bogiem, ani z duszą ani z wolnością nie ma nic wspólnego - byleby tylko nie obrażono Konieczności. Nauki pozytywne sprawdziły się przed Koniecznością jeśli metafizyka chce zdobyć prawo do istnienia, powinna przede wszystkim zjednać sobie

${ }^{13}$ Zasada ta jest zawarta w tytule jednego z dzieł Szestowa; Por. Лев Шестов, Sola fide - Только верою. Греческая и средневековая философия. Аютер и Церковь (Paris: YMCA-PRESS, 1966).

${ }^{14}$ Por. Cezary Wodziński, Wiedza a zbawienie. Studium myśli Lwa Szestowa (Warszawa: IFiS PAN, 1991), 47.

${ }^{15}$ Szestow rozumiał filozofię jako walkę; por. Szestow, „Pamięci wielkiego filozofa", 248-248. 
przychylność anankē. Notwendigheit und strenge Allgemeinheit sind sichere Kennenzeichen einer Erkenntnis a priori („Konieczność i ścisła ogólność są pewnymi oznakami poznania a priori") - jedynego poznania, któremu człowiek może ufać. Jest to dla Kanta prawda oczywista, tak jak oczywiste jest, że deus ex machina jest najniedorzeczniejszym z założeń albo że jeśli ein höheres Wesen (wyższa istota) ingeruje w ludzkie sprawy, to filozofia nie ma nic do zrobienia w naszym świecie ${ }^{16}$.

Wypowiedź Szestowa interpretuję jako negatywnie sformułowany postulat wpisania w system Kanta idei deus ex machina oraz „wyższej istoty", innymi słowy - postulat uwzględnienia cudów, tak jak uwzględniał on każdy możliwy sąd syntetyczno-a priori. W tej kwestii system Kanta interesował Szestowa - podobnie jak miało to miejsce u Karsawina - tylko jako jeden z przykładów racjonalizmu, czyli jako przykład odwołania się do "czystego rozumu”. Potwierdzeniem tego jest zestawienie stanowisk Georga Wilhelma Friedricha Hegla i Kanta. Referując je, Szestow napisał między innymi:

Albo - i tu ujawniłoby się prawdziwe „zainteresowanie” Hegla, a raczej podstawowa przesłanka jego myślenia - oświadczyć: wszelkiego rodzaju cuda, zarówno te, o których zaświadcza się w Biblii, jak i te, o których się mówi w Baśniach z tysiąca i jednej nocy - to nic nie warta bzdura, odrzucana przez rozum teoretyczny i całkowicie nie do przyjęcia dla rozumu praktycznego. Czy też, jak mówi Kant: deus ex machina jest najniedorzeczniejszym z możliwych założeń, a idea wyższej istoty ingerującej w ludzkie sprawy sama przez się oznacza koniec wszelkiej filozofii. Myślenie tak Kanta, jak i Hegla opiera się całkowicie na tych założeniach ${ }^{17}$.

Można stwierdzić, że dla Szestowa deus ex machina to wręcz idea fix, ponieważ powracał do niej wielokrotnie i na różne sposoby, nie wykluczając przy tym ujęcia negatywnego. Referując poglądy Kanta i zarazem dokonując interpretacji przesłanek warunkujących zajmowane przez niego stanowisko, ideę tę nieustannie miał na względzie.

Idei celowości w przyrodzie (finalizm), na przykład, przyjąć nie można: autonomia tego rodzaju przypominałaby o deus ex machina albo o wyższej istocie i byłaby zamachem na uświęcone prawa anan $e^{-18}$.

Negatywne ustosunkowanie się rozumu teoretycznego zarówno do idei deus ex machina, jak i tego wszystkiego, co w sposób bezpośredni lub pośredni się z nią wiąże, można uznać za coś oczywistego. Trudno

${ }^{16}$ Lew Szestow, Ateny i Jerozolima, przeł. Cezary Wodziński (Kraków: Znak, 1993), 161-162; por. także 154-155.

17 Tamże, 154-155.

18 Tamże, 162. 
oczekiwać od rozumu teoretycznego, że $\mathrm{w}$ przypadku zasadniczych kwestii metafizyki (Bóg, nieśmiertelność duszy, wolna wola) i wynikających z nich problematycznych zagadnień, nie wykluczając przy tym idei deus ex machina, dokona jednoznacznych rozstrzygnięć lub rozwiąże problem inaczej niż poprzez jego odrzucenie. Jednak zdaniem Szestowa rozum praktyczny w filozofii Kanta również nie rozwiązuje żadnych problemów, nie realizuje żadnych zdroworozsądkowych czy też wynikających z wiary postulatów, ponieważ - jak uzasadnia to w ironiczny sposób (ironią w system Kanta) - "skromny i bezpretensjonalny" rozum praktyczny nie ulegnie pokusom praw "Konieczności i Mechanizmu”. Natomiast w przypadku wątpliwości, na przykład czy wszystko w świecie można wyjaśnić za sprawą prawa Konieczności, według Szestowa „rozum praktyczny podpowie nam, iż trzeba to przyjąć z dużą powściągliwością i lepiej powiedzieć, że w świecie coś dzieje się tak, jak gdyby (als ob) losami świata był ktoś zatroskany"19.

Radykalnego i bezkompromisowego Szestowa nie interesowało jednak wyjaśnianie w oparciu o zasadę „tak, jak gdyby”. Tym bardziej nie interesowały go praktyczne konsekwencje wynikające $z$ takiej zasady, zatem życie "tak, jak gdyby". Albo Bóg z jego nieograniczoną (zatem niepojętą przez rozum teoretyczny i niemożliwą do przyjęcia przez rozum praktyczny) zdolnością do działania może byłe uczynić niebyłym, a niebyłe byłym, co - jeszcze raz należy powtórzyć - w „normalnym świecie” jest ideą szalona, albo „normalny świat” jest nienormalny.

W ujęciu interpretacyjnym z rozważań Szestowa w bezpośrednim nawiązaniu do filozofii Kanta wynika bardzo ważna konsekwencja, która polega na tym, że według Szestowa "czysty rozum” to zarówno rozum teoretyczny, jak i rozum praktyczny.

W części artykułu zatytułowanej Ironia w system Kanta, próbując odpowiedzieć na pytanie, dlaczego Karsawin przytacza tak niedorzeczny przykład weryfikacji fenomenalizmu świata zewnętrznego, skonkludowałem, że „do skrytykowania systemu Kanta najprawdopodobniej wystarczyła Karsawinowi przeprowadzona przez samego Kanta krytyka metafizyki". Oznacza to, że Karsawina nie przekonywały inne rozstrzygnięcia i rozwiązania wprowadzone przez Kanta, w tym nie przekonało to, co miał do powiedzenia na temat rozumu praktycznego. Można zatem na zasadzie analogii do tego, co wynika z rozważań Szestowa, przyjąć, że według Karsawina „czysty rozum” również obejmował rozum teoretyczny i rozum praktyczny.

W oparciu o przyjęte założenie można z kolei, przynajmniej na zasadzie hipotezy, uwzględnić jeszcze jedną propozycję interpretacji. Karsawin nie wyraził co prawda tego wprost, ale podając przykład weryfikacji fenomenalizmu świata zewnętrznego przez gotowość do skoku przez

\footnotetext{
19 Tamże, 162.
} 
okno z piątego piętra, w konsekwencji zażądał od Kanta przyjęcia w ramach systemu nie tylko Boga, ale i tego, co ze względu na brak wiedzy i zrozumienia zazwyczaj określane jest mianem cudu. W systemie Kanta nie ma ani pierwszego, ani tym bardziej drugiego, dlatego rozpatrując rzecz z perspektywy filozofii Karsawina przyjęcie systemu Kanta prowadzi na manowce $\mathrm{w}$ tym sensie, że niczego nie wyjaśnia, ponieważ nie odnosi się do całości tego, co istnieje; natomiast zaproponowana próba weryfikacji fenomenalizmu świata zewnętrznego, jak milcząco zakładał Karsawin, z konieczności powinna skończyć się tragedią, co jest wystarczającym powodem do odrzucenia tego systemu.

Karsawin, chociaż nie wprost, robił zatem to samo co Szestow - żądał od Kanta przyjęcia Boga oraz cudu, co w ujęciu teoretycznym znaczyło przyjęcie istnienia Boga wraz z wiarą w niego jako fundamentalny element systemu, a nie tylko jako ewentualną hipotezę, której weryfikacji za sprawą rozumu - a jak celowo, żeby uniknąć niedomówień podkreślał Szestow, ani za sprawą rozumu teoretycznego, ani rozumu praktycznego - nie sposób dokonać.

Karsawin z racji tego, że w ramach „właściwego" systemu za absolutny ideał przyjął ideę rosyjska, w konsekwencji, kierując się wiarą i rozumem, ani nie doszedł do herezji, ani nie przyjął postawy gotowości do skoku przez okno z piątego piętra w celu weryfikacji fenomenalizmu świata zewnętrznego. Natomiast inaczej ma się rzecz u Szestowa, który - z racji tego, że za absolutny ideał przyjmuje coś całkowicie niewłaściwego - kierując się wiarą i rozumem, zarówno doszedł do herezji, jak i był gotowy do skoku.

Zakładając hipotetyczną dyskusję na temat deus ex machina, która mogłaby się odbyć między Kantem a Szestowem, ten ostatni, jako typowy radykalny Rosjanin działający zgodnie z rozumem i wiarą (fides et ratio), mógłby sprawę zakończyć w sposób następujący: „jeżeli wbrew temu, co dyktuje rozum teoretyczny, a rozum praktyczny nie chce nawet dopuścić przyjęcia tego jako możliwości, dasz wiarę i przyjmiesz ideę deus ex machina, to ja, zgodnie z propozycją Karsawina, wyskoczę przez okno z piątego piętra $\mathrm{w}$ celu udowodnienia fenomenalizmu świata zewnętrznego". Przy takim postawieniu sprawy należy dodatkowo założyć, że Szestow byłby pewien, że Kant, jak przystało na "prawdziwego" filozofa, mimo pokusy nie zmieni zdania. Gdyby jednak Kant spełnił postawiony warunek, to Szestowa i tak nie powinno już interesować to, czy otrzymany rezultat będzie wynikiem pozytywnym, czy negatywnym. Przyjęcie przez Kanta warunku postawionego przez Szestowa znaczyłoby bowiem zrezygnowanie z "przewrotu kopernikańskiego" wraz z wszystkimi wynikającymi z niego konsekwencjami i wprowadzonymi 
ustaleniami na rzecz zbudowania systemu. W ten sposób Szestow osiągnąłby swój cel, stwarzając kolejną możliwość możliwości poprzez przełamanie (zanegowanie) konieczności, do której przyjęcia zmusza „czysty rozum".

Zaproponowanie hipotetycznej dyskusji oraz założenie, że Kant na prośbę Szestowa nie zmieniłby niczego w swoim systemie, a już z pewnością nie wprowadziłby idei deus ex machina, bierze się z tego, że Szestow nie miał złudzeń co do losów systemu Kanta. W jednej z ostatnich swoich rozpraw - poświęconej pamięci Husserla - Szestow, konkludując rozważania, zajął wobec systemu Kanta stanowisko, które różnie może być interpretowane. Zwrócę uwagę tylko na literalne ujęcie tego zagadnienia. Nie przesądzam przy tym, czy jest to ostatni, w pełnym tego słowa znaczeniu, głos w sprawie nie tylko filozofii Kanta, ale również racjonalizmu w ogóle, czy też jest to tylko kolejna prowokacja zmuszająca do - wzorem zgłaszanego przez Husserla postulatu - zrewidowania zasadności dotychczasowego sposobu uprawiania filozofii. Wypowiedź Szestowa w literalnym ujęciu może być uznana za deklarację poddania się, złożenia broni po długiej, wyczerpującej i nieprzynoszącej rozstrzygnięcia walce (filozofia), ale jest to również smutna, aczkolwiek niepozbawiona nadziei konstatacja.

Oświecony człowiek nigdy nie uda się po prawdę do starej, stworzonej przez niewykształcony naród, księgi, tak jak nie zgodzi się przeciwstawić krzyków Hioba, płaczu Jeremiasza i gromów Apokalipsy racjom rozumu z jego oczywistościami. Filozofia nie wyrzeknie się Kanta ${ }^{20}$.

Jedno z postawionych przez Szestowa pytań w bezpośrednim nawiązaniu do tej konstatacji brzmi:

Czy znaczy to, że Entweder-Oder [albo-albo - A.O.] Husserla i Kierkegaarda zostało na zawsze odrzucone przez ludzi? ${ }^{21}$

Na tak sformułowane pytanie - łącznie z pozostałymi, które w ujęciu interpretacyjnym redukuję do pytania o ostateczny triumf rozumu i konieczności - Szestow odpowiedział negatywnie. Jednak w przeciwieństwie do tego, czego można byłoby oczekiwać od typowego Rosjanina, tym razem nie wyraził swojego stanowiska w sposób radykalny, wzmacniając je tylko uogólnieniem wyrażającym wspomnianą już nadzieję:

${ }^{20}$ Szestow, „Pamięci wielkiego filozofa”, 267.

21 Tamże. 
Nie sądzę. W ogólnej ekonomii ludzkich duchowych działań wysiłki zmierzające do przezwyciężenia oczywistości mają swoje, mimo że niewidoczne, niedające się ocenić, ale jednak ogromne znaczenie ${ }^{22}$.

\section{Bibliografia}

Карсавин Лев Платонович. 1993. „Восток, Запад и русская идея”. W: Лев Платонович Карсавин, Сочинения. 157-216. Москва: РАРИТЕТ (wyd. pol. Karsawin Lew. 2007. Wschód, Zachód i rosyjska idea, przeł. Lilianna Kiejzik, Michał Bohun. Zielona Góra: Oficyna Wydawnicza Uniwersytetu Zielonogórskiego).

Шестов Лев. 1993. „Афины и Иерусалим”. W: Дев Шестов, Сочинения в 2-х томах. Том 1. Москва: НАУКА (wyd. pol. Szestow Lew. 1993, 2009. Ateny i Jerozolima, przeł. Cezary Wodziński. Kraków: Znak).

Szestow Lew. 1993. Ateny i Jerozolima, przeł. Cezary Wodziński. Kraków: Znak.

Шестов Дев. 1992. Киргегард и экзистенчцииальная философия. Глас вопиющего в пустыне. Москва: Прогресс - Гнозис (wyd. pol. Szestow Lew. 2003. Kierkegaard i filozofia egzystencjalna. Głos wołajacego na pustyni, przeł. Jacek Prokopski. Kęty: Antyk).

Szestow Lew. 2007. „Pamięci wielkiego filozofa (Edmund Husserl)”.W: Lew Szestow, Spekulacja i objawienie, przeł. Jacek Chmielewski. 243-267. Kęty: Wydawnictwo Marek Derewiecki.

Шестов Лев. 1966. Sola fide - Только верою. Греческая и средневековая философия. Аютер и Церковь. Paris: YMCA-PRESS (wyd. pol. Szestow, Lew. 1995. Sola fide - tylko przez wiarę, przeł. Cezary Wodziński. Warszawa: PWN).

Wodziński Cezary. 2009. Św. Idiota. Projekt antropologii apofatycznej. Gdańsk: słowo/obraz terytoria.

Wodziński Cezary. 1991. Wiedza a zbawienie. Studium myśli Lwa Szestowa. Warszawa: IFiS PAN.

\section{Streszczenie}

Celem artykułu jest wykazanie, że pomimo odmienności stanowisk Karsawina i Szestowa ich krytyka ",czystego rozumu” i racjonalizmu wychodziła od bardzo podobnych przesłanek i miała przynajmniej jedno wspólne źródło inspiracji filozofię Kanta. Punktem wyjścia rozważań jest stanowisko Karsawina, według którego "typowy" Rosjanin nie może żyć (istnieć) bez "absolutnego ideału”. Zdaniem Karsawina niewłaściwe przyjęcie (rozumienie) „absolutnego ideału” 
prowadzi do negatywnych konsekwencji. Wykazuje je, między innymi, na przykładzie filozofii Kanta.

Słowa kluczowe: „czysty rozum”, deus ex machina, idealizm, egzystencjalizm, Karsawin, Szestow, Kant

\section{Karsavin's and Shestov's Critique of "Pure Reason"}

\section{Summary}

The goal of the article is to demonstrate that in spite of differences between philosophy by Karsavin and by Shestov, their critique of "pure reason" and rationalism has similar premises and at least one common source of inspiration. This source is Kant's philosophy. According to Karsavin, a "typical" Russian cannot live (exist) without the "absolute ideal". In Karsavin's opinion, misunderstanding of "absolute ideal" leads to negative consequences. He shows it, inter alia, by example of Kant's philosophy.

Keywords: "pure reason", deus ex machina, idealism, existentialism, Karsavin, Shestov, Kant 